\title{
Remote speech-language-hearing follow-up: monitoring cochlear implant users in the immediate postoperative period
}

Roberta Garcia Monteiro Vieira ${ }^{1}$ https://orcid.org/0000-0001-9370-7432

Lilian Muniz Ferraz ${ }^{2}$

https://orcid.org/0000-0002-0450-4148

Ana Augusta de Andrade Cordeiro ${ }^{2}$

https://orcid.org/0000-0002-8458-3367
Instituto Materno Infantil de Pernambuco, Recife, Pernambuco, Brasil.

2 Universidade Federal de Pernambuco UFPE, Departamento de Fonoaudiologia, Recife, Pernambuco, Brasil.

Conflict of interests: Nonexistent

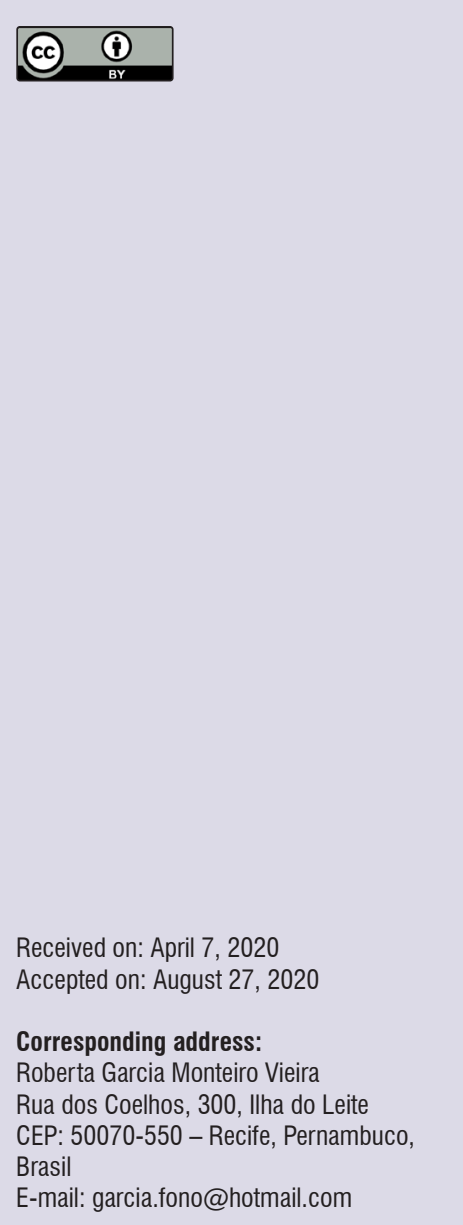

\section{ABSTRACT}

Purpose: to verify whether the complementary remote speech-language-hearing follow-up is an effective tool in the monitoring of cochlear implant users in the immediate postoperative period.

Methods: a total of 26 relatives participated in the study, divided into two groups: with and without remote speech-language-hearing follow-up. By the time the device was activated, they were given instructions on four subjects: the device, family, school, and speech-language-hearing therapy. After one week, the group with remote speechlanguage-hearing follow-up started receiving such care via mobile phone. In the inperson follow-up visit, a questionnaire was administered (containing questions on the guidance given), as well as an interview with the parents/guardians that received the remote follow-up. The data obtained from the questionnaire were analyzed with Fisher's exact test, with $5 \%$ significance. The qualitative data were analyzed based on Bardin's theme content analysis technique.

Results: there was a significant difference in the quantitative results between the groups regarding "device" and "school". In the qualitative data, it was verified that the remote speech-language-hearing follow-up furnished greater assurance to the relatives of the cochlear implant users, helping them in the therapeutic process and at school.

Conclusion: the complementary remote speech-language-hearing follow-up proved to be an effective tool in the subjects researched, especially regarding the handling of the device and guidance to school.

Keywords: Audiology; Remote Consultation; Cochlear Implantation; Hearing Aid 


\section{INTRODUCTION}

The cochlear implant $(\mathrm{Cl})$ is an electronic device whose function is to stimulate the auditory nerve. Its most relevant benefit is the possibility of perceiving high-frequency sounds, enabling its user to recognize speech sounds more easily. However, acquiring the most complex auditory skills depends on biological factors (such as the integrity of the pathways of the peripheral and central auditory systems), psychosocial factors, and the users' and their relatives' involvement in the therapeutic process ${ }^{1,2}$

Thus, using the $\mathrm{Cl}$ alone does not ensure the adequate development of the communicative potentialities. It is also necessary to involve both the user and their family in the therapeutic process conducted by the multidisciplinary team.

The parents and/or relatives of $\mathrm{Cl}$ users need to offer support and make important decisions that will have an impact on their health and communication. They need to seek new skills and adapt to an unknown reality, coping with unexpected feelings and situations, in addition to doubts and expectations. These cause stress on the family, which is common to such situations ${ }^{1}$.

From the auditory assessment to the in-person postoperative $\mathrm{Cl}$ follow-up, many parents and relatives stay in the waiting room and share their experiences. This support network is of great worth as it is one of the few places where these individuals are understood and listened to without judgment. Also, many anxieties related to the surgical and postsurgical processes are calmed with these talks ${ }^{3}$.

Nonetheless, the in-person follow-up in the $\mathrm{Cl}$ service - as recommended by the ministry's regulatory law no. 2,776, of December 14, 2018 - may run against geographical and economic barriers. Among the possible consequences, a higher rate of broken outside $\mathrm{Cl}$ parts and nonadherence to the treatment stand out, making the auditory and language development a more difficult process. In this regard, it is necessary to provide more objective and recurrent guidance to each family, considering their specificities.

Reflecting on these issues, the increased number of cochlear implantations in the last years, the irregular distribution of reference centers, and the country's vast territory, the remote speech-language-hearing follow-up can be seen as a potential communication alternative between $\mathrm{Cl}$ users and/or relatives and the health services.
Oftentimes, the $\mathrm{Cl}$ users and their companions need to travel long distances to receive care, which makes it important to provide remote speech-language-hearing follow-up. Such an approach can improve the effectiveness and continuity of the treatment, minimizing the distance and decreasing the direct and indirect costs with transportation, food, and lodging. Such costs are paid by the municipality, the state, and/or the patient. Moreover, there is the unproductive time spent traveling, the children's absence from school, and the adult's absence from their professional activities.

Given this context and the growth in the field of telehealth, this research aimed to verify whether the complementary remote speech-language-hearing follow-up is an effective tool in the monitoring of cochlear implant users in the immediate postoperative period.

\section{METHODS}

This research was approved by the Human Research Ethics Committee of Centro de Ciências da Saúde da Universidade Federal de Pernambuco - UFPE, $P E$, Brazil, under evaluation report number 3.231.833. The data collection started after the participants had signed the informed consent form and/or informed assent form.

This mixed-method study had a qualitative-quantitative approach and was characterized as analytical and interventional. The data was collected at the cochlear implant outpatient center of one of the accredited hospitals in the health care program for the person with hearing loss in the state of Pernambuco.

A total of 26 relatives of children with a cochlear implant, aged one to 10 years, participated in this study. The participants were divided into two groups: with (WRF) and without (WORF) complementary remote speech-language-hearing follow-up, following the decision to perform the surgery. The relative of the first user that underwent surgery during the collection period was directed to the WRF, and the second one, to the WORF - and so on until the total number of participants per group was completed, totaling 13 in each. The participants were first contacted when they scheduled the $\mathrm{Cl}$ surgery.

The participants were selected by convenience. The inclusion criteria for the WRF group were their being responsible for a child that had undergone cochlear implantation during the collection period, at the hospital where the study was conducted, chosen by convenience, and having access to a device (mobile, tablet, or 
computer) capable of accessing the internet, opening images and receiving video calls. The inclusion criterion for the WORF group was their being responsible for a child that had undergone cochlear implantation during the collection period, at the hospital where the study was conducted. The exclusion criteria for both groups were the informed consent form not being signed, nonattendance to the assessment and/or follow-up visit at the time scheduled for data collection, and failure in inside or outside $\mathrm{Cl}$ parts during this period. Specifically, for the WRF: being responsible for a child whose oral and/or written language was not enough to enable them to receive remote follow-up or that missed one of the in-person visits and/or $50 \%$ of the remote speech-language-hearing follow-up consults. None of the participants was in either of these situations.

As part of the routine, the outer component was activated 30 days after the surgery, both in the WRF and WORF. This three-hour-long procedure was conducted by the speech-language-hearing therapist responsible for the research. It comprised the activation of the outer component and instructions, following a script with information on four subjects: the device, family, school, and speech-language-hearing therapy.

The part on the device approached the following aspects: instructions on handling and maintaining the whole accessories kit the user receives when the $\mathrm{Cl}$ is activated, according to its model and manufacturer, and the frequency it is used. The part on the family approached issues such as the importance of the involvement of everyone that is regularly in contact with the $\mathrm{Cl}$ user to provide them a rich oral language stimulation environment, besides their commitment to speech-language-hearing therapy. The part on the school approached the importance of the partnership between family and school professionals, to ensure the effective use of the device in that environment and the best benefit toward the $\mathrm{Cl}$ user's educational development. It also approached the use of the $\mathrm{Cl}$ and the practice of sports, as well as the hygiene of the device when the child arrives from school. The part on speechlanguage-hearing therapy approached issues such as starting the therapy as early as possible and the importance of the family being present in the sessions to learn what is being done and continue the stimulation at home.

The contents were presented in PowerPoint slides. At both moments - activation and instruction - the relatives were free to ask questions when they felt the need.
After activating the outer component, according to the ministry's regulatory law no. 2776, of December 18,2014 , the next follow-up visit for new programming (mapping) must take place in two months. Following this recommendation, the participants in the WORF group left the activation having already scheduled the follow-up visit.

As for the WRF group, the complementary remote speech-language-hearing follow-up started one week after the activation, in hybrid mode - i.e., both synchronous (real-time interaction with the patient) and asynchronous (the information was collected and stored without the need for the user to be connected at that moment). Eight 20-minute encounters were promoted, which took place once a week, for two consecutive months, at a time previously scheduled between the speech-language-hearing therapist/ researcher and each user's family, through WhatsApp. Their purpose was to follow more closely the family's and $\mathrm{Cl}$ user's adherence to the therapy, as well as providing the remote speech-language-hearing follow-up with instructions on the themes approached.

WhatsApp was chosen because all the patients already used this application and were familiar with it. This choice was made before the speech-languagehearing telehealth clarification note ${ }^{4}$ was published on the website of the Brazilian Conselho Federal de Fonoaudiologia (CFFa, Federal Speech-LanguageHearing Council), on April 6, 2020.

Each week, the follow-up was conducted via WhatsApp approaching a different subject, chosen to organize the information in a way that the user and relatives would better understand the aspects involved in this initial process.

Twenty-four hours before each remote speechlanguage-hearing follow-up, the researcher sent a video with information on the subject they were approaching that week. Hence, the relative had access to material they would discuss in the following day's remote visit.

The first five minutes of the complementary remote speech-language-hearing follow-up were spent with the questions the relatives had about the video that had been sent and/or anything that happened during that week. In the following 10 minutes, the speechlanguage-hearing therapist gave that week's instructions, and the last five minutes were once again open to discuss any doubts the relatives might have. This cycle was repeated throughout seven weeks. In the eighth session (the last one), no specific subject was proposed; instead, the speech-language-hearing 
therapist gave instructions according to the participants' needs. In these visits - both with preestablished subjects and the final one - the relatives' questions were mostly related to handling and maintaining the device (according to the $\mathrm{Cl}$ brand), the effective and systematic use of the $\mathrm{Cl}$ (both at home and school), and aspects of the speech-language-hearing therapy. The flowchart with the follow-up process described above is shown in Figure 1.
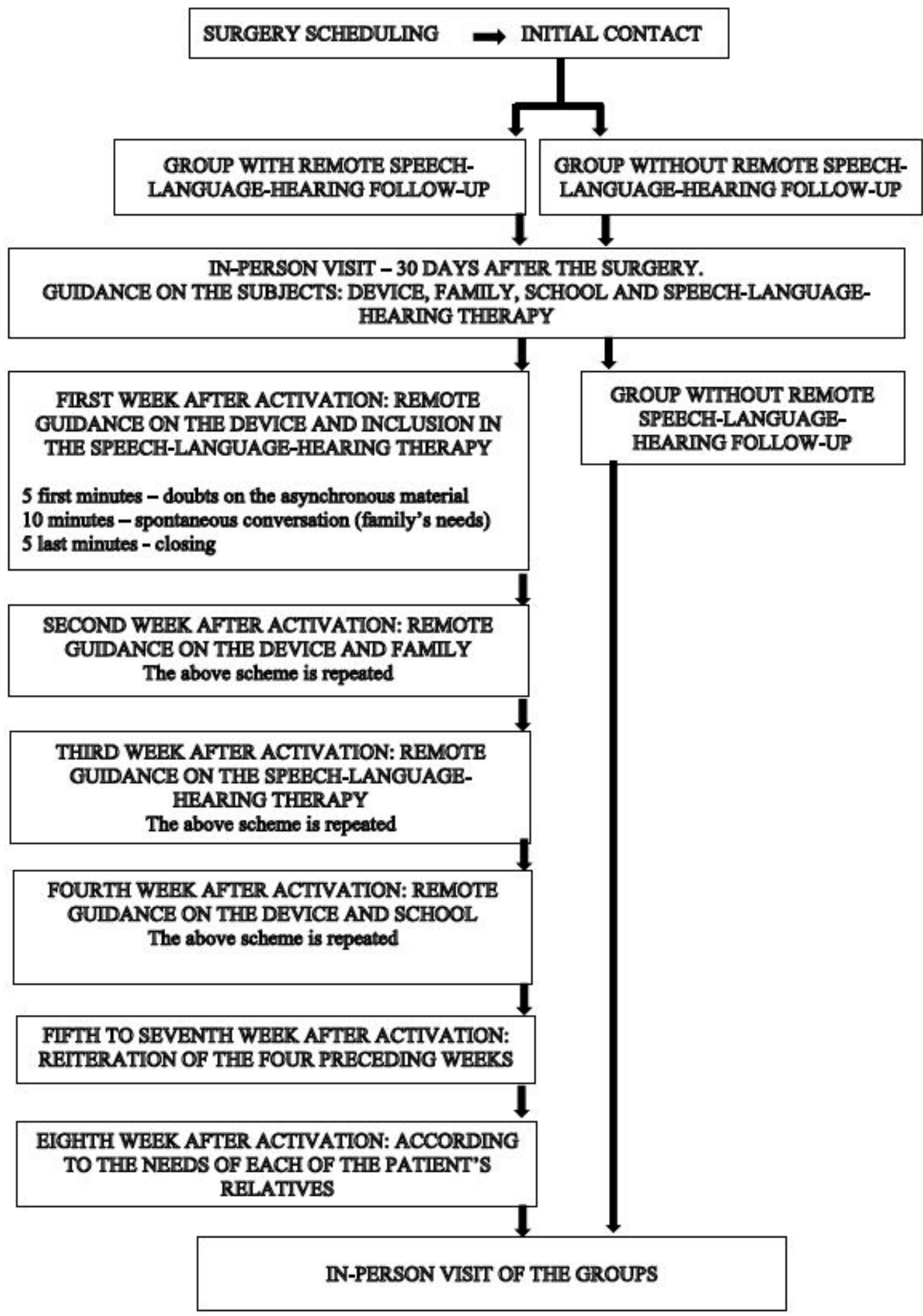

Figure 1. Flowchart of the remote health care 
Two months after the device was activated, the WRF and WORF groups attended the in-person mapping. A questionnaire was administered to both groups, divided into two parts: Part I - with questions about sociodemographic, educational, and clinical issues; Part II with 26 multiple-choice questions about the assessed subjects, distributed as follows: 12 questions about the device, five about the family, six about the school, and three about the speech-language-hearing therapy.

For the questions in Part 2, the instrument had a gradual Likert scale. When answering the questionnaire, based on this scale, the participants specify their level of agreement with the question they are answering. They could choose one of the following options: strongly agree, partially agree, neither agree nor disagree, partially disagree, and strongly disagree. The questions were presented positively and negatively - i.e., inverting part of the statements. This is recommended, to avoid the halo effect, which is when the respondent chooses an option exclusively based on the answer given in the previous statement ${ }^{5}$.

In this same visit, those in the WRF group were individually interviewed; this procedure was recorded, with no interference of the researcher. The guiding questions in the interview were: What did you think of the remote follow-up? During the two months of follow-up, did anything unexpected happened with the device, school, and/or speech-language-hearing therapy?

When the mapping and interview were finished, both the WORF and WRF groups left with a follow-up visit scheduled for two months later.

The quantitative data were registered in a databank developed for this research with the help of the SPSS program (Statistical Package for the Social Sciences), version 15.0. For the data analysis, the normality hypothesis was verified, in order to choose the statistical tests. Afterward, statistic techniques were used (such as Fisher's test), which compare independent groups. The results were presented in tables and graphs.

The normality of the groups was analyzed with the Kolmogorov-Smirnov test, rejecting the normal distribution hypothesis when $p<0.05$. To compare the values before and after applying the technique, Student's t-test was used for related samples, and Wilcoxon's test, for the variables with normal and nonnormal distribution, respectively; to compare the case and control groups, Student's t-test was used for independent samples, and Mann-Whitney's test, respectively, for the variables with normal and nonnormal distribution with a $5 \%$ significance level.

\section{QUESTIONNAIRE - PART 1 - SEMI-STRUCTURED}

\begin{tabular}{|c|c|}
\hline \multicolumn{2}{|r|}{ PERSONAL DATA } \\
\hline Name: & Date of birth: \\
\hline Address: & Telephone number: \\
\hline \multicolumn{2}{|c|}{ Schooling: ( ) Preschool ( ) Middle school ( ) Not applicable } \\
\hline School: ( ) public ( ) private & Regular class: ( ) Yes ( ) No \\
\hline Date of cochlear implantation: & Cochlear implant manufacturer: \\
\hline Cochlear implant model: & Cochlear implant side: \\
\hline \multicolumn{2}{|c|}{$\begin{array}{l}\text { PERSON RESPONSIBLE FOR THE REMOTE } \\
\text { SPEECH-LANGUAGE-HEARING FOLLOW-UP }\end{array}$} \\
\hline Name: & Date of birth: \\
\hline Address: & Telephone number: \\
\hline \multicolumn{2}{|c|}{ Schooling: ( ) Preschool ( ) Middle school ( ) High school ( ) Higher education } \\
\hline Type of access to the internet: & Relation to the user: \\
\hline
\end{tabular}

Figure 2. Questionnaire - Part 1 - Semi-structured 


\section{QUESTIONNAIRE - PART 2 - STRUCTURED}

\section{It is difficult to turn the processor on and off}

2. Are not there any difficulties in placing the processor on your son/daughter?

3. It is quite complicated to change the programming.

4. The parts' warranty periods are confusing.

5. It is difficult to recharge the battery.

6. Alcohol is the best product to clean the device.

7. It is not necessary to use the dehumidifier every day.

8. It is better to use the disposable battery to save the rechargeable one.

9. I should not worry with the time it takes to recharge the battery.

10. I expected I would be able to handle all the parts as soon as the implant was activated.

11. I am concerned that the device might fail, and I will not know how to solve it.

12. I do not feel ready to answer other people's questions on the handling of the device.

\section{FAMILY}

13. The family is important to the work of auditory rehabilitation.

14. The cochlear implant group offers support to the family.

15. Those responsible for a child with a cochlear implant need to know how to handle the device.

16. No additional guidance meetings are necessary.

17. Not all those responsible for the child knows how to handle the device.

\section{SCHOOL}

18. The family gets involved in the school process.

19. The school is not important in the process of getting adapted to the device.

20. Educators do not need to know how to handle the device.

21. Educators must remove the device for intense physical activities.

22. Educators must not remove the device for recess.

23. Those responsible for an implanted child must instruct the educators regarding the use of the device.

\section{SPEECH-LANGUAGE-HEARING THERAPY}

24. The child with a cochlear implant must systematically have speech-language-hearing therapy.

25. Skipping speech-language-hearing therapy does not delay the language and auditory development of a child with a cochlear implant.

26. Programming the device substitutes the speech-language-hearing therapy.

Figure 3. Questionnaire - Part 2 - Structured

The qualitative data, resulting from the interview with those responsible for the implanted children in the groups with remote speech-language-hearing follow-up, were transcribed and analyzed based on Bardin's theme content analysis technique (2011). This technique presupposes some stages, defined by the author as pre-analysis; exploration of the material, or decoding; treatment of the results obtained; inference and interpretation.

Reading and listening to the speeches during the exploration of the material made it possible to identify the cores of meaning and their decoding. Subcategories emerged and were grouped in themed categories, following the criteria of homogeneity, mutual exclusion, relevance, objectivity, and fidelity. To protect the identity of those responsible for the children, they were referred to as R1, R2, R3, and so on, until R13.

\section{RESULTS}

In the analysis of the sociodemographic, educational, and clinical data, observed in Table 1, it was verified that most of the participants (65.4\%) were from the city of Recife and its Metropolitan Area and that over one third (34.6\%) were from the inland. It was also verified that most of them (64\%) studied in private schools. Regarding the $\mathrm{Cl}$ surgery, $53.8 \%$ were simultaneous bilateral, and $46.2 \%$ were unilateral. Regarding the parents/guardians' schooling level, 
Table 1. Sociodemographic, educational, and clinical data

\begin{tabular}{|c|c|c|}
\hline Variables & $N(26)$ & $\%$ \\
\hline \multicolumn{3}{|l|}{ Origin } \\
\hline Recife, Brazil & 10 & 38.5 \\
\hline RMA & 7 & 26.9 \\
\hline Inland & 9 & 34.6 \\
\hline \multicolumn{3}{|c|}{ Parents' schooling level } \\
\hline Preschool & 2 & 7.7 \\
\hline Middle school & 4 & 15.4 \\
\hline High school & 16 & 61.5 \\
\hline Higher education & 4 & 15.4 \\
\hline \multicolumn{3}{|l|}{ School $(* *)$} \\
\hline Public & 9 & 36.0 \\
\hline Private & 16 & 64.0 \\
\hline \multicolumn{3}{|l|}{ Interpreter(**) } \\
\hline Yes & 7 & 28.0 \\
\hline No & 18 & 72.0 \\
\hline \multicolumn{3}{|l|}{ Cochlear implant side } \\
\hline Right & 7 & 26.9 \\
\hline Left & 7 & 26.9 \\
\hline Simultaneous bilateral & 12 & 46.2 \\
\hline
\end{tabular}

Source: The author

$\left.{ }^{*}\right)$ - RMA = Recife Metropolitan Area; $\mathrm{Cl}=$ cochlear implant

$\left.{ }^{* *}\right)$ The total number of participants in some topics vary because one child did not attend school.

it was verified that $61.7 \%$ (the majority) had finished high school, $15.4 \%$ had finished middle school, the same percentage had higher education, and $7.7 \%$ had finished preschool.

To verify whether the complementary remote speech-language-hearing follow-up is an effective tool in the monitoring of cochlear implant users in the immediate postoperative period, an inferential statistical analysis was conducted, using Fisher's exact test with a $5 \%$ significance level. In it, the answers given by the WORF and WRF concerning the four subjects assessed were compared.

There was a statistically significant difference between the WORF and WRF groups, which indicates that the WRF group benefitted from the complementary remote speech-language-hearing follow-up (Table 2). It was also verified that, regarding "device", there was a statistically significant difference between the groups in the questions about changing the programming, parts warranty period, battery charge, use of disposable batteries, and clarifying doubts. Regarding "school", there was a difference between the groups concerning the importance of school in the process of adapting to the device, and the educators' understanding of how to handle the device and use it during physical activities and recess.

There were no statistically significant differences between the WORF and WRF groups in two assessed subjects: "Family" and "speech-language-hearing therapy". 
Table 2. Crossed agreement between the groups with and without remote follow-up regarding the subjects assessed

\begin{tabular}{|c|c|c|c|}
\hline \multirow{3}{*}{ Variables } & \multicolumn{2}{|c|}{ Group } & \multirow{3}{*}{ p-value * } \\
\hline & WRF & WORF & \\
\hline & n (\%) & n (\%) & \\
\hline \multicolumn{4}{|l|}{ Device } \\
\hline There are no difficulties placing the processor & $12(92.3)$ & $9(69.3)$ & 0.322 \\
\hline It is complicated to change the programming & $0(0.0)$ & $6(46.2)$ & 0.015 \\
\hline The warranties of the parts are confusing & $0(0.0)$ & $9(69.2)$ & 0.001 \\
\hline It is difficult to recharge the battery & $0(0.0)$ & $6(46.2)$ & 0.015 \\
\hline Alcohol is the best product to clean the device & $10(76.9)$ & $9(69.2)$ & 1.000 \\
\hline Should not use the dehumidifier every day & $0(0.0)$ & $8(61.5)$ & 0.002 \\
\hline Disposable batteries save the rechargeable battery & $0(0.0)$ & $10(76.9)$ & 0.001 \\
\hline Should not worry about the time it takes to charge the batteries & $0(0.0)$ & $6(46.2)$ & 0.015 \\
\hline Activated implant means good handling of the device & $3(23.1)$ & $6(46.2)$ & 0.411 \\
\hline The device can fail, and I will not know how to solve it & $12(92.3)$ & $11(84.6)$ & 1.000 \\
\hline I do not feel ready to answer questions & $1(7.7)$ & $12(92.3)$ & 0.001 \\
\hline \multicolumn{4}{|l|}{ Family } \\
\hline The CI group offers support to the family & $13(100.0)$ & $11(84.6)$ & 0.480 \\
\hline Not all those responsible for the child knows how to handle the device & $7(53.8)$ & $12(92.3)$ & 0.073 \\
\hline \multicolumn{4}{|l|}{ School } \\
\hline The family gets involved in the school process & $13(100.0)$ & $11(84.6)$ & 0.480 \\
\hline The school is not important in the adaptation process & $0(0.0)$ & $6(46.2)$ & 0.015 \\
\hline Educators do not need to know how to handle the device & $0(0.0)$ & $7(53.8)$ & 0.005 \\
\hline Educators must remove the device for physical activities & $12(92.3)$ & $5(38.5)$ & 0.011 \\
\hline Educators must not remove the device for recess & $12(92.3)$ & $5(38.5)$ & 0.011 \\
\hline Those responsible for the child must instruct the educators & $13(100.0)$ & $9(69.2)$ & 0.096 \\
\hline \multicolumn{4}{|l|}{ Speech-language-hearing therapy } \\
\hline Skipping speech-language-hearing therapy does not delay the development & $2(15.4)$ & $4(30.8)$ & 0.645 \\
\hline The programming substitutes the speech-language-hearing therapy & $1(7.7)$ & $6(46.2)$ & 0.073 \\
\hline
\end{tabular}

Source: The author

${ }^{\star}$ ) Fisher's exact test

Based on the questions asked to those responsible for the implanted children that received complementary remote speech-language-hearing follow-up, five themed categories were identified in their speeches, described as follows:

\section{Themed Category 1: The guidance given in the complementary remote speech-language-hearing follow-up is positive and instructive.}

All the parents/guardians participating in the group with complementary remote speech-language-hearing follow-up referred to the guidance given as positive. The speech of some of them is transcribed below.

"It's very good! If we have any difficulty handling the device, the remote follow-up helps a lot." ... (R1)

"It's very important to clarify any doubts... but the videos that are sent beforehand are the most instructive and we can improve week by week the handling of the device, and the problem-solving." ... (R2)

"I found it very interesting! ... And with the telephone consultations, I could have all my questions answered about many issues that came up as it was used."... (R3)

\section{Themed Category 2: The guidance given in the complementary remote speech-language-hearing follow-up is convenient and practical as it is not necessary to go to the doctor's office.}

“We've already been to many visits to the doctor, but it gets harder because of the wheelchair. So, it was wonderful not having to go somewhere to have our questions answered because l'd have to take a leave from work." ... (R4) 
"I found it very nice because we don't have to go somewhere to have our questions answered, we don't have to be absent from work, nor our kids from school." ... (R5)

"I'm from Petrolina, so I can't go back and forth all the time to have our questions answered." ...

\section{Themed Category 3: The guidance given in the complementary remote speech-language-hearing follow-up strengthens the conduct of parents/ guardians.}

"The guidance they gave us was better than I expected. I've learned and managed to be calmer to help my son in this first moment, in terms not only of the device but also the therapies and school."...

"My son gave us a little trouble in the first week to start using it. My mom asked me not to put it on him because it was harming him, but the consultations I had with you made me stronger to insist, and even helped to instruct my mother."... (R2)

"... The people were always asking me if she wasn't hearing... As the loss was progressive, she can speak very well, as you know, but she can't understand much. And with the consults, I became strong to explain to people that it wasn't just like that, turn it on and she's listening!"...

\section{Themed Category 4: The guidance given in the complementary remote speech-language-hearing follow-up helps the schools that are not ready to receive implanted children and deal with the device.}

"The school didn't want my son to go to class without the implant because they didn't know how to handle it. And as I told them it was expensive, that we needed to be careful with it, they got even more worried. But you told me many things that I passed on to them, and I even showed them the videos, which they were more willing to accept." ...

"The school didn't want him to go at first until he was adapted but I insisted and now they already help in the process."... (R11)

"The school at first didn't want him to use it because they were afraid that he would lose it there. Little by little, though, after talking a lot, they understood that that was one of the places where he was stimulated the most and that he couldn't do without it."...

\section{Themed Category 5: Difficulty maintaining the therapy.}

"The speech-language-hearing therapy is too difficult there; he's not doing it. I stimulate him at home with some instructions you gave me."... (R9)

"I had a hard time finding a speech-language-hearing therapist that wanted to see him."... (R8)

"The speech-language-hearing therapists are complicated, they say they don't know how to deal with this device. I couldn't understand the difference but as we had the weekly follow-ups, I had my questions answered and I realized people are not well informed." ... (R6)

\section{DISCUSSION}

This study is of interest because the complementary remote speech-language-hearing follow-up can be an alternative to help the relatives of $\mathrm{Cl}$-using children in the postoperative process concerning the subjects assessed, namely: device, family, school, and speechlanguage-hearing therapy.

One of the important aspects to consider regarding the sociodemographic characteristics of the participants of the study is the place where they live. More than a third of the population came from the inland Pernambuco, Brazil, a characteristic that is observed in other pieces of research using remote follow-up tools, which will be presented in the sequence.

A study was developed at the audiology research center of the craniofacial anomalies rehabilitation hospital with the University of São Paulo. It aimed to verify the benefits and limitations of the remote $\mathrm{Cl}$ programming and implant this health care model in the hearing health services In Brazil. One of the professionals was located at the reference center and the other, at a center more than $1,500 \mathrm{~km}$ away. It was concluded that this health care model has advantages for various reasons, such as the decentralization of the hearing health services, the professionals' development and training, the reduction in costs to the Sistema Único de Saúde (SUS, the Brazilian public health care system), and the systematic follow-up of the implanted patients ${ }^{6}$.

A randomized clinical trial conducted at the University of São Paulo also assessed the effectiveness 
of synchronous teleconsultation to program $\mathrm{Cl}$ systems in users followed up in a cochlear implant program accredited by the SUS. The focus was on those that lived far from the health care center. The participants were satisfied with the consultation and reported that teleconsultation can be seen as a feasible alternative to in-person care and that its clinical application made the routine easier?.

Considering the irregular nationwide distribution of specialized professionals and the patients' need to travel long distances to receive health care, the importance of the remote follow-up is justified due to the vast Brazilian territory. Studies highlight how $\mathrm{Cl}$-users and their companions need to travel long distances to receive health care, generating direct and indirect costs with transportation, food, and lodging. These expenses are paid by the municipality and/or state, and by the patient. Also, the time spent traveling forces the children and their companions to be absent from their school and/or work routine. Moreover, it makes it easier for older adults, who only have to travel in case they have a real need ${ }^{8-10}$.

As previously observed in the words of some of the parents/guardians in the remote follow-up group, there is an explicit reference to the issue of traveling, due to accessibility (one of the children was in wheelchairs), geographical distance (one of the children lived $713 \mathrm{~km}$ away from the reference center), or the work activities of those responsible for them (not having to take a leave from work). Therefore, not having to travel makes the communication between the $\mathrm{Cl}$ user/caregiver and the reference center more accessible, providing broader knowledge of the issues involving the device, therapy, and school, besides a systematic follow-up of the patient.

Other characteristics to be emphasized are the type of school and the presence of an interpreter in some schools. It was verified that most of the participants study in private schools. Despite being from the private sector, which makes one think the school can afford more qualified human resources, most of the speeches of the parents/guardians who received complementary remote speech-language-hearing follow-up revealed that the schools were unprepared to receive the children with $\mathrm{Cl}$ and uninformed about how to handle the device. Their reports highlighted that they were the ones who passed on to their children's teachers the information received in the remote speechlanguage-hearing follow-up. Their speeches also point out that, based on the instructions they received, some educators changed their attitude and accepted these children, trying to understand them and give them support.

A study conducted in Rio de Janeiro, Brazil, with public school teachers showed that many schools, although being inclusive and with specialized educational attention, are not yet capable of working with people with a disability. Among the various factors, the lack of professional training stood out, as well as the absence of training courses to provide the continuous education of teachers who have in their classrooms deaf children who use a hearing aid and/or cochlear implant ${ }^{11}$. Hence, regarding this topic, the situation in private schools is noticeably similar to that of the public ones.

Given the above, it is observed that the remote speech-language-hearing follow-up spreads knowledge and helps the parents/guardians to instruct the professionals in the schools, as some of them changed their initial attitude. Also, almost all the relatives that received this type of attention stated that they felt ready to answer questions related to the device.

These data corroborate the view that the remote speech-language-hearing follow-up is an important alternative in the process of including the implanted children in the schools. It is a useful tool in the continuing education of educators who can participate remotely in training courses to handle the device and to develop strategies toward the best school development of the $\mathrm{Cl}$ users.

It is interesting to observe that the only type of support some schools give is the interpreter. This datum leads to a discussion about the lack of alignment between the health and the education policies. Seemingly, the schools are not prepared to receive implanted children, which can be observed in the words of some of the parents/guardians in the present study. The right to receive all the necessary support in the general education system is provided by law, according to the Specialized Educational Attention Policy, established by the decree no. 7,611, of November 17, 2011'2. Nonetheless, such a right is not secured to everyone. In other words, in the organizational framework for the education of deaf people, actions directed to $\mathrm{Cl}$ users are not included.

Indeed, the issues related to the device are of great importance because the child will only hear if they are using it and if it is in good condition. In this context, it is necessary to provide more specific instructions to the family to reinforce the importance of using and/or 
taking care of the device, as well as the aspects related to their responsibility.

In Bauru, SP, Brazil, a website was developed to guide the parents of children that use hearing aid (HA). As a result, it was noticed that there were a greater interaction and adherence to the treatment, besides a decrease in the indexes of broken parts ${ }^{13}$.

Once the device stops working, the $\mathrm{Cl}$ user stops hearing. Consequently, they are no longer auditorily stimulated until the equipment returns from the technical support, impairing their auditory rehabilitation process in the social, school, and therapeutic contexts.

After some research in Bauru, a group of researchers found that patients reported the desire to have access to educational material in an accessible language, to complement the information provided by the professionals available inside and outside the clinical setting. To meet this demand, the group developed online content for distance guidance regarding the use and care of the HA. This resulted in users with fewer doubts and complaints, and more adherence to using the device ${ }^{14}$.

The WRF and WORF groups did not have statistical differences regarding their opinion on the family's responsibility in maintaining the device in working conditions and the involvement everyone must have in the auditory rehabilitation process of the $\mathrm{Cl}$-using child. In the WRF group, the parents/guardians reinforced the importance of this mode of follow-up, both concerning the difficulties of traveling to the center and the acquisition of information.

A study conducted with HA users reveals that counseling through teleconsultation was efficient for their follow-up, as significant changes were verified in the frequency of use of the device. The results also indicate that therapeutic support via teleconsultation with adults/older adults favored a change in the users' behavior. Before, with some discomfort, they did not want to use it any longer. After the counseling, greater adherence to the use was verified. These findings corroborate the data from the present research ${ }^{15}$.

Concerning the subject of speech-language-hearing therapy, both groups recognized its importance. Some of the parents/guardians in the WRF group spoke about the difficulty in having access to such service, making the auditory and linguistic development process more difficult.

The ministry's regulatory law no. 2,161 , of July 17 , 2018, follows the previous one concerning the recommendation of individual speech-language-hearing therapy, in that the reference center must furnish to the $\mathrm{Cl}$ user such therapy sessions twice a week ${ }^{16}$. However, that is not what happens, due to the lack of specialized professionals and the high number of implantees; and, when the center does have the service, the user has to face territorial barriers.

The ideal would be to find a place where the $\mathrm{Cl}$ user could have speech-language-hearing rehabilitation near their home. Also, according to the parents/ guardians in the WRF group, the professionals that are not in the reference centers say that they are not trained for this type of health care, which is again revealed in the themed category 5 .

In this sense, the complementary remote speechlanguage-hearing follow-up can be a solution to the issue of the speech-language-hearing therapist's training when they do not know nor master the field of auditory rehabilitation. Such training could be offered, not only to the professionals of more isolated municipalities but also to those that live closer to the reference center, since they would not need to take a leave from their work activities.

In a study on the training of specialized professionals in the field of auditory rehabilitation of children with hearing loss, it was verified that an asynchronous teleconsultation is an important tool in telehealth. It produced a positive effect on the speech-languagehearing therapies assessed, which is demonstrated by the index of reliable change in the quality of the therapies. The participating speech-language-hearing therapists showed satisfaction with the asynchronous teleconsultation experience, giving a positive evaluation of the service ${ }^{17}$.

The speech-language-hearing therapy must count on the support of the relatives, as they are the ones who spend most of the time with the $\mathrm{Cl}$-using children. Research conducted at the São Paulo Medical School, aimed to verify the proposal of a program intended to offer guidance to the parents of $\mathrm{Cl}$-using children. The children's language performance is positively influenced by the family's involvement and mother-child interaction, as well as by the family's linguistic input. Hence, they developed a rehabilitation and guidance program involving linguistic and auditory skills. Statistically, there was no significant difference between the group submitted to this program and the one with traditional care. Nonetheless, the parents who received the differentiated follow-up reported changes in their children's lexicon ${ }^{18-20}$. It can be verified that the extra guidance and treatments brought about benefits to the 
users of the device and their relatives, even though it was not statistically observed.

The qualitative data that emerged in two categories revealed that the guidance remotely given was both positive and instructive. One of the participants even pointed out that it went beyond their expectations. The participants also highlighted that they reinforced the conduct they should take when other people and adversities had made them unsure. These data are quite interesting because, although the participants had different schooling levels, they seemed to benefit from the remote speech-language-hearing follow-up.

Generally speaking, the studies cited in this discussion, as well as the findings in this research, point to the remote speech-language-hearing follow-up as an important auxiliary tool in the follow-up process of $\mathrm{Cl}$ users, their families, and the professionals involved in the rehabilitation process.

Lastly, it is important to emphasize that, although WhatsApp is one of the most popular and most used mobile messaging applications worldwide, with approximately 1.5 billion users ${ }^{21}$, besides being a promising communication tool between patients and professionals ${ }^{22,23}$, it does not offer the cryptography and security measures to ensure privacy. Therefore, using this application for teleconsultation or telemonitoring in speech-language-hearing therapy is not recommended by the Brazilian CFFa.

On the other hand, it must be taken into account that this research was carried out in 2019, based on the CFFa resolution no. 427, of March 1, 201324. Thus, the CFFa recommendation no. 20, of April 23, 202025, and the clarification note on speech-language-hearing telehealth, of April 6, 20204, had not yet been issued. Both highlight the importance of following in Brazil the technical standards regarding data storage, handling, and transmission, ensuring professional secrecy, confidentiality, and privacy. The said note also points out that the speech-language-hearing therapist must try to learn what solutions comply with international security protocols, such as HIPAA compliance. This North American regulation (Health Insurance Portability and Accountability Act - HIPAA) establishes a set of security standards to protect health information, which must be followed in clinical practice and further research in speech-language-hearing telehealth.

\section{CONCLUSIONS}

The results obtained point to the complementary remote speech-language-hearing follow-up as an effective tool in the subjects researched, especially regarding the handling of the device and guidance to school. This follow-up modality provided a greater assurance and autonomy to the users and their relatives, as well as greater proximity between the family and the treatment center.

It is suggested that further research be conducted involving more than one reference center, with a greater number of participants and remote follow-ups, complying with the existing legislation that regulates teleconsultation and telemonitoring in speechlanguage-hearing therapy.

\section{REFERENCES}

1. Pádua FR, Morettin M, Otake MY. Grupo de apoio para pais de crianças com implante coclear. Estud Pesq Psicol [internet]. 2016 [citado 2019 dez 10];16(3):800-15. Disponível em: https://www. redalyc.org/articulo.oa? $\mathrm{id}=451854875008$

2. Cordeiro BB, Banhara MR, Mendes CMC. Ganho auditivo e influência do tempo de privação auditiva na percepção de fala em usuários de implante coclear. Audiol., Commun. Res. [Internet]. 2020 [cited 2020 June 25]; 25:e2282. Disponível: https://doi.org/10.1590/2317-6431-2019-2282

3. Aiello CP, Ferrari DV. Teleaudiology: efficacy assessment of an online social network as a support tool for parents of children candidates for cochlear implant. CoDAS [internet]. 2015 Oct [cited 2020 Feb 19]; 27(5):411-8. Available from: https:// doi.org/10.1590/2317-1782/20152013061

4. Conselho Federal de Fonoaudiologia. Nota de esclarecimento sobre a Telessaúde em Fonoaudiologia. Recomendação 18-B 17 de mar de 2020. Disponível em: https://www. fonoaudiologia.org.br/cffa/index.php/2020/04/ nota-de-esclarecimento-sobre-a-telessaude-emfonoaudiologia/

5. Nogueira R. Elaboração e análise de questionários: uma revisão da literatura básica e a aplicação dos conceitos a um caso real. Rio de Janeiro: UFRJ, 2002. 27 p. 350

6. Zumpano $\mathrm{CE}$, Bevilacqua MC, Frederigue-Lopes NB, Costa OA. Programação remota dos sistemas de implante coclear. Rev Soc Bras Fonoaudiol [Internet]. 2009 [citado 2020 Feb 19]; 14(4):539-46. Available from: https://doi.org/10.1590/S151680342009000400019 
7. Comerlatto Junior AA. Investigação da eficácia da teleconsulta na programação do implante coclear [internet] [tese]. São Carlos (SP): Universidade de São Paulo; 2016 [citado 2020 Feb 19]. Disponível em: https://www.teses.usp.br/teses/ disponiveis/82/82131/tde-22062016-101840/pt-br. php

8. Spinardi-Panes AC, Lopes-Herrera SA, Maximino LP. Telehealth in speech, language and hearing sciences: ethical and legal issues. Rev. CEFAC [Internet]. 2013 [cited 2020 Fev 19];15(4):1040-43. Available from: https://doi.org/10.1590/ S1516-18462013000400035

9. Vitti SV, Molina CF, Blasca WQ, Sigulem D, Torres Pisa I. Auditory training web-based system for elderly user of hearing aids. J Health Inform [internet]. 2019 [cited 2019 Oct 20]; 11(3):74-8. Available from: http://www.jhi-sbis.saude.ws/ojs-jhi/ index.php/jhi-sbis/article/download/645/368

10. Rakawa-Belaunde AM, Carleto NG, Favoretto NC, Espírito Santo C, Franco EC, Bastos JRM et al. Development and evaluation of a website with Alzheimer's disease information and its consequences for communication. Audiol Commun Res [Internet]. 2018 [cited 2020 Feb 19]; 23:e1956. Available from: https://doi. org/10.1590/2317-6431-2017-1956

11. Costa JP, Kelman CA, Góes ARS. Inclusão de alunos com implante coclear: a visão dos professores. Rev Educ Espec [internet]. 2015 [Citado 2019 ago 02]; 28(52):325-38. Disponível em: http://dx.doi.org/10.5902/1984686X14784

12. Ministério da Educação e Cultura (BR). Decreto no 7.611, de 17 de novembro de 2011. Brasília, DF: MEC, 2011. Disponível em http://www.planalto.gov. br/ccivil_03/_ato2011-2014/2011/decreto/d7611. htm

13. Bastos BG. Telessaúde: avaliação de um website como ferramenta de auxílio ao aconselhamento de pais de crianças usuárias de aparelho de amplificação sonora individual [internet] [dissertação]. Bauru (SP): Universidade de São Paulo, Faculdade de Odontologia de Bauru; 2011 [citado 2019 Ago 15]. Disponível em: https:// www.teses.usp.br/teses/disponiveis/25/25143/ tde-23082011-145543/pt-br.php

14. Jokura PR, Ferrari DV. Elaboração de um conteúdo online com informações sobre a audição, perda auditiva e aparelhos auditivos. In: Anais do $27^{\circ}$ Encontro Internacional de Audiologia, 2012 Abr
14-17, Bauru, BR [internet]. São Paulo; Academia Brasileira de Audiologia; 2012 [citado 2019 Ago 15]; 1: 276. Disponível em: https://www.audiologiabrasil. org.br/eiabauru2012/pg.php?pg =anais

15. Nielsen CB, Carneiro LA. Telehealth: verification of the effectiveness of an orientation program and audiological counseling for adults through teleconsultation Distúrbios Comum [internet]. 2015 Dec [cited 2018 Dez 10]; 27(4):696-706. Available from: https://revistas.pucsp.br/index.php/dic/article/ view/22255/18824

16. Ministério da Saúde (BR). Portaria no 2161, de 17 de Julho de 2018. Diário Oficial da União [internet]. 2018 Jul [citado 2020 Fev 15]; 137(1 seç): p. 55. Disponível em: http://www.in.gov. $\mathrm{br} /$ materia/-/asset_publisher/Kujrw0TZC2Mb/ content/id/31890149/ do1-2018-07-18-portaria-n-2161-de-17-de-julho-de-2018-31890131

17. Maniçoba RDS, Balen AS, Brazorotto JS. Teleconsultoria assíncrona para fonoaudiólogos de crianças com deficiência auditiva: relato de caso. Bras Inov Tecnol Saúde [Internet]. 2018 Nov [citado $2020 \mathrm{Fev} \mathrm{19];8(1):23.} 24$ p. Disponível em: https://periodicos.ufrn.br/reb/article/view/12609

18. Monteiro CG, Cordeiro AAA, Silva HJ, Queiroga BAM. Children's language development after cochlear implantation: a literature review. CoDAS [internet]. 2016 [cited 2020 Fev 19]; 28(3):319-325. Available from: https://doi. org/10.1590/2317-1782/20162015151

19. Moura TMR. O resultado fonoaudiológica da audição e da linguagem associa-se com a percepção do resultado dos pais e professores de crianças usuárias de implante coclear. Rev Educ [internet]. 2017 [citado 2019 Jun 02];12(2). Disponível em: http://revistas.ung.br/index.php/ educacao/article/view/3085

20. Mota JM, Tavares TF, Koji RT, Bento RF, Matas CG, Andrade CRF et al. Effect of the parents guiding program for the lexical development of children using cochlear implant. Intl Arch Otorhinolaryngol [Internet]. 2011 [cited 2020 Feb 19]; 15(1):54-8. Available from: https://doi.org/10.1590/S1809-4 8722011000100008

21. Agência Brasil [Internet]. Brasília: Empresa Brasil de Comunicação; [citado 2019 set 23]. Disponível em: http://agenciabrasil.ebc.com.br/geral/noticia/ 2019-05/usuarios-de-smartphone-devem-atualizarwhatsapp-orienta-empresa 
22. Garbin AJl, Pacheco Filho AC, Santos Pacheco KT, Garbin CAS. O uso do Wattshap na relação dentista-paciente: uma revisão de literatura. Rev Bras Odontol Leg. 2019;6(3):73-81.

23. Catapan SC, Calvo MCM. Teleconsulta: uma revisão integrativa da interação médico-paciente mediada pela tecnologia. Rev. bras. ed. med. 2020;44(1):e002.

24. Conselho Federal de Fonoaudiologia. Resolução CFFa no 427, de 1o de março de 2013. Disponível em: https://www.fonoaudiologia.org.br/resolucoes/ resolucoes_html/CFFa_N_427_13.htm

25. Conselho Federal de Fonoaudiologia. Recomendação CFFa no 22, de 26 de junho de 2020. Disponível em: https://www.fonoaudiologia. org.br/cffa/wp-content/uploads/2020/06/ Recomendacao_CFFa_22_2020.pdf 